\title{
Administrative Reform as a Tool in Fighting Communal Marginality
}

\author{
Walter Zsilincsar
}

The topic presented might - at first glance - seem to be too regionally focused but is in fact deeply rooted in the present EU and the worldwide economic and financial crisis, reaching far beyond Austria's borders. Meanwhile, more than 1,000 Austrian communities of a total of 2,358 (1998) have failed to achieve a balanced communal budget. The reasons for this unpleasant situation are manifold and, as the recent national and international banking scandals have shown, they have even been caused by criminal activities (high-risk speculations, corruption, etc.), the lack in skills and qualifications of party-politicians, nepotism, etc.

All these failures have evoked broad interest in Austria's mass-media for more than two years now. However, we must not forget that there are a lot of other reasons, structural in nature, for the financial crisis of so many Austrian communities. Among these structural reasons, one must first mention the small size of the majority of Austria's communes. More than one quarter of them have less than 1,000 inhabitants, and there are still many with below 500 citizens. In such small communities administration is simply inefficient. Another reason for the communal crisis must be seen in various prestige projects (sports grounds, spas, etc.) but also in the costs of maintenance and administration of hospitals, schools, kindergartens, fire brigades, etc.), and in the support and subvention of other social institutions. The paper discusses administrative reform as one tool in fighting against the present communal crisis, which quite often ends up in communal marginality.

Key words: Administrative reform, communal marginality, structural reform, financial crisis, fusion ${ }^{1}$, Austria

\section{Administrativna reforma kao mjera protiv marginalnosti na lokalnoj razini}

Na prvi pogled može se učiniti da je tema problematizirana u ovom radu regionalnoga karaktera, no ustvari je duboko ukorijenjena u trenutačnu ekonomsku i financijsku krizu te nadilazi granice Austrije. Više od tisuću austrijskih općina od ukupno 2358 (1998. godine) ne uspijeva ostvariti uravnotežen općinski proračun. Razlozi za takvu situaciju višestruki su, a nedavni nacionalni i međunarodni bankarski skandali pokazuju da su dijelom povezani is kriminalnim aktivnostima (visokorizične spekulacije, korupcija i s1.), manjkom sposobnosti i vještina političara, nepotizmom i sl.

Svi ti neuspjesi pokazali su se vrlo zanimljivima austrijskim medijima, međutim ne treba zaboraviti da mnogi drugi, strukturni problemi utječu na financijsku krizu austrijskih općina, među kojima je važna i njihova veličina. Tako više od četvrtine austrijskih općina broji manje od tisuću stanovnika, a postoji i značajan broj općina s manje od petsto stanovnika. U tako malim jedinicama lokalne samouprave administracija je neučinkovita. Razlog leži i u raznim tzv. prestižnim projektima poput toplica i sportskih dvorana, ali i u 
održavanju bolnica, vrtića i vatrogasnih društava i upravljanju njima te subvencioniranju drugih institucija. U radu se problematizira administrativna reforma kao mjera suzbijanja krize koja često završava marginalizacijom lokalnih jedinica samouprave.

Ključne riječi: administrativna reforma, marginalnost općina, strukturna reforma, financijska kriza, fuzija, Austrija

\section{INTRODUCTION}

The recent international financial crisis that was a direct consequence of the American real estate collapse and huge speculative transaction losses of the U.S. banking sector of 2008 swept throughout Europe due to the globalized nature of the world. There it affected not only the banking sector and the nation states' fiscal policies, but, in a particular way, the individual communities themselves.

Thus, the focus of this paper will be mainly on the consequences of this financial crisis, especially for small and medium-sized Austrian communes with a background of peripherality and/or marginalization. As to the reasons for the communal crisis, they will not be sought so much on the international level as mentioned above but primarily on a "home-made" basis.

There is a broad spectrum of causes and effects to be considered, which ranges from economic, social, cultural or party-political motives to very personality-related factors.

An overall recipe for the solution of the problem seems to be seen in structural reforms and the system's change. Our short analysis of the various attempts to find ways out of the communal crisis underlines quite clearly how major the difficulties to be overcome are. The reform of Austrian communal structures has always been and still is wearisome.

The topic of "structural reform" has been occupying the Austrian media for quite a while now and it seems to threaten politicians and constituents similarly, like the sword of Damocles. In the recent past, a topic can hardly be found that has put normal people and their political representatives in a constant flurry for such a long time (since 2010).

For more than one year the author has followed regional media to analize the press coverage of this topic. Interviews with communal politicians supported the gathering of information.

The analysis of newspaper articles collected over 2 years has finally revealed a dismal image of our political culture today.

\section{SOME CAUSES AND MOTIVES FOR COMMUNAL REFORM}

In addition to the international financial crisis, the present precarious situation of the great bulk of communities results from various other reasons. Among them, party-political quarrelling, maladministration, financial mismanagement, corruption, incompetence of decision-makers, unnecessary competition instead of co-operation between communes, an inadequate regional policy, or an unbalanced distribution of tax revenues among the single 
administrative bodies, etc. should be mentioned. However, probably the most important reason for the structural weakness of many communities lies far back in the past: this is the too great number and the generally too small size - both as to the number of inhabitants and to the areal extensions - of the administrative units.

The number of the communes in the Austrian province of Styria $\left(2001: 16,392 \mathrm{~km}^{2}\right.$, pop. $1,183,303$ ) has been almost halved from 1004 to 563 in the early 1970 s; after a few more communal fusions since then, Styria until 2013 still consistsed of 542 communities. Seventy-six of them are counted as the smallest administrative units with less than 500 inhabitants. Population forecasts reckon with further losses of inhabitants in 304 of the 542 communes (Roth, 2011, 10-11).

Dramatic population falls, especially in marginalized communities, are increasing the necessity of incurring debts to finance communal expenditures. Thus in 2011, 194 Styrian towns and cities failed to achieve an balanced ordinary budget. Spendings on necessary infrastructural measures (road conservation, water supply, sewage and waste disposal, winter services, etc.), social expenditures (kindergardens, care for the aged and disabled, fire brigades, sports and leisure facilities, etc.), cultural institutions and events (choral societies, brass-music orchestras, folklore organizations, religious institutions, etc.) by far exceeded the financial potential of the communes. Nevertheless, costly sponsoring of local sports clubs and the realization of diverse prestige projects (expensive and lavish design of public facilities like thermal spas) seems still to be a main "hobby" of mayors and the leading political parties. Since 1978, 8 thermal spas have been opened in Styria, giving former marginalized Eastern Styria a new corporate identity, that of the "Thermenland" (thermal region). Today, 9 modern thermal spas are making Styria the most important thermal region in Austria. Having been a commercial success story during the initial phase, with growing competition from the installation of more and more new spas and hotels, some of the spas have encountered financial instability, and with them, their communities. In most cases, the latter had encouraged private investors to implement these (prestige) projects. They supported them either directly through financial aid as cash contributions, long-running loans to be paid back at very low rates of interest, or indirectly by means of tax exemption or reduction for a certain period of time. And they offered free or low-cost sites for the foundation of enterprises, free supply of electricity, water and other communal infrastructure, etc. It is quite obvious that such support can weaken the communal budgets dramatically, even leading to insolvency in some cases.

Some typical examples from the recent past in the Austrian province of Styria may illustrate this situation. The mayor of the former Upper Styrian coal-mining town of Fohnsdorf(pop. 2012: 7,900, 1900: 10,013), a Social Democrat, has made several attempts to overcome the economic disturbances that resulted from the closing down of mining activities in 1978. The first successful measure was the installation of a large shopping mall far away from the town's own centre along the main highway following the Mur valley and close to the communal borderline with the political district capital city, Judenburg (pop. 2012: 9,319). The new shopping centre drew away a remarkable amount of purchasing power and local taxation revenues from Judenburg, caused the closure of retail shops and of smaller enterprises and, moreover, the moving of Judenburg's biggest department store to a new location in the vicinity of Fohnsdorf's new shopping mall. 
Despite the tensions that had arisen from Fohnsdorf's communal activities between the two social democratically ruled cities, the mayor of Fohnsdorf continued with his ambitious development plans based upon an absolute majority in the city council. Thus, despite deep-seated doubts about the economic feasibility of the project, he carried through his plans for a thermal spa. Soon after its opening in 2010, the spa turned out to be a financial disaster, almost forcing the city into bankruptcy. As a consequence the mayor was expelled from the Social-Democratic Party and forced to resign. The community was required to repay State loans of $€ 12 \mathrm{Mn}$.

Only some $50 \mathrm{~km}$ away from Fohnsdorf, Styria's second city, Leoben, (pop. 2012: 24,645 ) also invested in a similar prestige project, the "Asia Spa". Here, too, the huge costs of more than $€ 31 \mathrm{Mn}$, an insufficient frequency of users, and poor fiscal control has been criticized (Rossacher, Kleine Zeitung, Graz, 8.3.2012).

In Zeltweg (pop. 2012: 7,188), another Styrian town, the mayor has been accused for having caused a disastrous communal budget as a consequence of the obscure sponsorship of the local ice-hockey club.

\section{THE FINANCIAL CRISIS OF THE COMMUNES}

Statistical data about the returns on communal taxes, as published annually by the Styrian Statistical Office, have underlined the fact that primarily size (i.e. the number of inhabitants) and economic productivity are the determining variables within the communal budgets. Consequently Graz, the provincial capital (pop. 2012: ca. 300,000), although having only $21.5 \%$ of the Styrian population, obtains $30 \%$ of the total communal return. A similar situation can be found in the communities of the so-called "Speckgürtel" (bacon-belt) around Graz or in the industrial row of the Upper-Styrian Mur- und Mürz Valleys. These economic hotspots located in the central positions of the province, have superior transportation facilities - an airport, turnpikes, railways - and are profiting from the concentration of shopping centres, high-tech industries, manufacturing and excellent educational institutions (the Technical Universities of Leoben and Graz, University of Graz, University of Applied Sciences in Graz, etc.).

On the other hand, the small communities in the peripheral mountainous regions and agrarian districts in the eastern and southern parts of Styria generate the lowest incomes from communal and property taxes. Thus, with an average of $€ 1,077.00$ (2010) tax income per head of all Styrian citizens, there exists a wide gap between the tax quota of the richest (Raaba near Graz: $€ 2,610.00$ ) and the poorest community of Breitenfeld near Leibnitz $(€ 590.00)$ although these places are separated from each other by roughly $50 \mathrm{~km}$ only (Fig. 1, Kübeck, Kleine Zeitung, Graz, 24.11.2012).

Communal incomes in 2010 were only slightly lower than in 2009 , when they had decreased by $6.8 \%$ due to the general economic crisis. This means that the communal budgets of many Styrian communities were dramatically unbalanced, also due to rising expenditures for care of the elderly, youth welfare, or other social agenda. As an outcome of the stability treaty between the federal government, the provinces, and the communities 


\section{Highest tax revenues}

\begin{tabular}{|l|c|c|c|}
\hline \multicolumn{1}{|c|}{ Communities } & District & Inhabitants & $\begin{array}{l}\text { Tax revenue } \\
\text { per inhabitant }\end{array}$ \\
\hline 1. Raaba & GU & 2141 & 2610 Euro \\
2. Bad Radkersburg & RB & 1379 & 1982 Euro \\
3. Unterpremstätten & GU & 3563 & 1832 Euro \\
4. Lannach & DL & 3300 & 1710 Euro \\
5. Krottendorf & VB & 2382 & 1559 Euro \\
6. Graz & G & 256319 & 1557 Euro \\
\hline
\end{tabular}

\section{Lowest tax revenues}

\begin{tabular}{|l|c|c|c|}
\hline \multicolumn{1}{|c|}{ Communities } & District & Inhabitants & $\begin{array}{l}\text { Tax revenue } \\
\text { per inhabitant }\end{array}$ \\
\hline 1. Breitenfeld am Tannenriegel & LB & 194 & 590 Euro \\
2. Maierdorf & FB & 552 & 593 Euro \\
3. Piberegg & VB & 377 & 602 Euro \\
4. Aug-Radisch & FB & 296 & 611 Euro \\
5. Kulm am Zirbitz & MU & 342 & 618 Euro \\
6. Gschnaidt & GU & 356 & 618 Euro \\
\hline
\end{tabular}

Fig. 1 Highest and lowest tax revenues per inhabitant of Styrian communities (Kleine Zeitung, Graz, 24.11.2011)

Sl. 1. Najniži i najviši porezni prihodi po stanovniku štajerskih općina (izvor: Kleine Zeitung, Graz, 24. studenoga 2011.)

aimed at reducing their rate of indebtedness to below 3\% in keeping with EU standards. However, in order to fulfil its obligations, the federal government simply transferred some cost-intensive agenda items like nursing homes, care for refugees, etc. into the competence of the communities. In addition, the Styrian Association of Towns and Cities finds fault with the obvious discrimination of Styria in relation to the redistribution of overall tax incomes between the federal government, the provinces and communities.

These fiscal problems must be seen a driving force in the discussion of future communal fusion and/or co-operation (who are or feel themselves to be the potential winners or losers?) Earlier fusions in the provinces of Carinthia, Vorarlberg, or the Tyrol have underlined their effectiveness against the doubts of some politicians that communal fusion only becomes effective if it creates new communities of more than 10,000 inhabitants.

The Styrian community ordinances demand a balanced ordinary communal budget. Moreover, communities are meant to aim for financial scope that would enable them 
to realize projects by themselves. However, the reality is something different. In Styria in $2010,42 \%$ of the communes incurred total losses of $€ 45,069,909$ (Amt d. Stmk. Landesregierung, FA 16, 2012, 10).

But which measures could lead the communities out of their financial crises? The next chapter offers some solutions.

\section{ARE THERE WAYS OUT OF THE COMMUNAL CRISIS?}

Structural reforms within the various levels of the Austrian administration have been discussed for several years, yet without visible or sustainable success. In the perception of the majority of the Austrian population and the mass-media, the ruling coalition government in Austria between the Social Democrats that provides the Chancellor and the Peoples Party is being seen as one of inefficiency, of mutual blocking instead of co-operation, of political standstill, and of corruption. The situation in the 9 provinces/states (Austria is a federal state with a distinct federal constitution) is no different. Therefore, it was a veritable political sensation when the same two ruling parties in Styria decided in 2011 to stop quarrelling and to start co-operation for the country's sake.

This new policy was labelled "Reformpartnerschaft" (reform partnership). Among dozens of commentaries in the media, the author has chosen two which demonstrate quite clearly what this policy is expected to be about.

On November 23 $3^{\text {rd }}, 2011$ Gigler and Kübeck, under the headline "Liebesheirat als Prinzip ist besiegelt" (Love-match sealed as a principle) were reporting on the decision of the Styrian government to give up the hitherto existing obligation to form a government based on proportional representations of all political parties in the provincial government (Landtag) based on the number of their votes. From now on, governance was to be in the hands of those who were willing and able to form a stable government. The speakers of the Styrian Peoples Party valued these steps as "greatest democratic constitutional reform Styria had faced so far".

Together with the new rules for governing, and to give a visible sign of reaction to the financial crisis that had also been encountered by the provincial government, it was decided to reduce not only the number of government members from 9 to 7 but also that of the members of the provincial parliament, from 56 to 48 . These measures were expected to relieve the state budget by One Million Euro annually. The smaller parties in the government opposed the decision, primarily from fear of losing influence through the reduction in the number of members in the political bodies.

The new "reform-partnership" in the country, however, was not unquestioned (s. Albertani, Kleine Zeitung, Graz, 4.3.2011, 20f.). The decision of the 2 party leaders to rule the country as partners instead of as political opponents was intensively and even controversially discussed both on the national and on the communal level. Yet, whether the reform-partnership will survive the next general elections is an open question. Nonetheless, it is obvious that only the strong will and decision of the leading parties to co-operate on all political levels of the country have created the prospects for structural communal reforms. 
Finally, no concrete or generally accepted solutions to overcome the communal crisis have been found so far. The solution-finding process is just being started. Necessarily, possible ways out of the communal crisis will most likely be individual rather than general.

\section{STRUCTURAL COMMUNAL/ADMINISTRATIVE REFORMS}

There are several reasons for structural communal reforms. One is present and future population development. Population growth as well as decline are a challenge for communal budgets. Growing communities are confronted with additional costs for infrastructure, social welfare, administration, etc. whereas shrinking ones suffer from the widening gap between expanding costs for necessary communal activities and reduced incomes. An additional financial burden has arisen in the recent past from global climatic change that causes a rising number of natural hazards of dimensions unknown up until now, such as floods, avalanches, mud flows, rock slides, long-lasting catastrophic droughts, etc. In only the first half of 2012, the cost of the material damages caused by disastrous floods and land slides in Styria exceeded One Hundred Million Euros. Since mostly smaller communities in peripheral Alpine and Pre-Alpine parts of the country have been affected, the financial burden they have to bear is even greater and may well lead to financial collapse. In July 2012, catastrophic mudflows in Alpine Styria destroyed bridges, streets, railway tracks, single houses and whole villages. Since then the affected population has been rigorously pursuing preventive measures like the construction of dams and basins for the storage of floodwater. Whereas the federal government bears the construction costs, the communities have to carry the burden of all the successive expenditures e.g. for maintenance.

The creation of larger administrative units through communal fusion could distribute the financial burden more evenly and foster investments in the newly created community centres. This might reduce the threat of further population losses. Yet there is no guarantee in this respect as the experience from the last communal fusion in Styria in 1992 has shown. The city of Frohnleiten belonging to the Graz Metropolitan Area counted 6,062 inhabitants in 2011 whereas the city's population before fusion was 7,056 in 1979.

A further reason for communal fusion is the projected reduction in infrastructire costs. As a rule, smaller communities are more economical in this respect than larger ones, due to the fact that private activities and contributions are much more widely spread, which is cost-saving e.g. concerning water supply, waste and waste-water discharge, alternative energy supply, etc. Thus, for example, road conservation in the small Styrian community of Großstübing costs $30 \%$ less than in its bigger neighbouring towns (Übelbacher Silberwürfel, Dez. 2011, 4-5).

Total expenditures for infrastructure are the lowest in communities of between 2,001 to 2,500 inhabitants (Pitlink, Wirth and Lehrer, 2010). Despite that, communal fusion needs not turn out to be cost-saving or cost-neutral in the long run, especially if - as is expected by the government - financially weak communities should join richer ones. The expectations of the poorer communities concerning future infrastructural measures and standards are aimed towards significant cost reductions (compared with those existing in the richest ones). In the longer view, this seems unrealistic. In the near future, however, an upgrade of the new central places in peripheral regions is possible. 


\section{fusions:}

Schwaiger $(2012,2)$ lists some problems and questions in connection with communal

- Size requirements: there is no minimum size required, neither in the number of inhabitants nor by areal extension if two or more communes want to unite.

- What happens to the former communal coats-of-arms? After fusion, the new mayor has to apply for a new one; however, in the case of general agreement, an already existing coat-of-arms could also be chosen for the united communities.

- How should the former communities place names be handled? Normally, the mayors of all the communes ready for fusion make proposals from which a new (old) name will be chosen. Former place names can survive as names of subordinate cadastral (communal) units.

- Existing parish communities are not touched by the administrative reform.

- What happens to those local administrative offices and communal properties that will not be needed any longer? This question must be solved through negotiations.

- How should the local voluntary fire brigades be treated? A very emotional discussion arose on this question, since in many cases the voluntary fire brigades had become institutions of local identity during their history. Therefore, the politicians decided not to touch existing locations.

- Will the population in the communities affected support the project? After initial doubts, the answer is a clear YES. Following opinion poll results of spring 2012, nearly $70 \%$ of Styrians, regardless of what political party they belonged to, supported the idea of communal fusion - namely, the fusion of smaller communities to strengthen their economic power. "The courage to do the right things bears fruit" (Albertani, Kleine Zeitung, Graz, 7.4.2012,8).

Despite the clear vote of the Styrians for the fusion of communities, one must not neglect the fact that there is also opposition to the proposal.

"No to fusion" is the title of an article by C. Hofer in Woche Graz-Umgebung Südost from April 11 ${ }^{\text {th }}, 2012$, where he quotes the mayor of a community south of Graz, who comments on a survey among his citizens who had voted unequivocally $-76 \%$ pros in an extensive voter turnout of $84 \%$ - for retention of the original status of their community: "The mass turnout demonstrates that the citizens do care about the future development of their place of residence".

Little enthusiasm for a fusion was also reported from the political district of Mürzzuschlag in Upper Styria. Whereas the bigger towns and cities are open-minded as regards communal administrative reform, most of small communities remain sceptical, fearing the loss of their independence (Kleine Zeitung, Graz, 7.4.2012, 28).

Despite the conviction of the political representatives of small administrative units of up to 2,500 inhabitants that their work is more effective and cost-saving, the Association of Austrian Towns and Cities (Österreichischer Städtebund) issued warnings because of the high administrative expenses, namely in communes of the same size class as quoted 
Administrative expenses in communities: data in Euro per capita, 2010 , according to number of inhabitants in communities

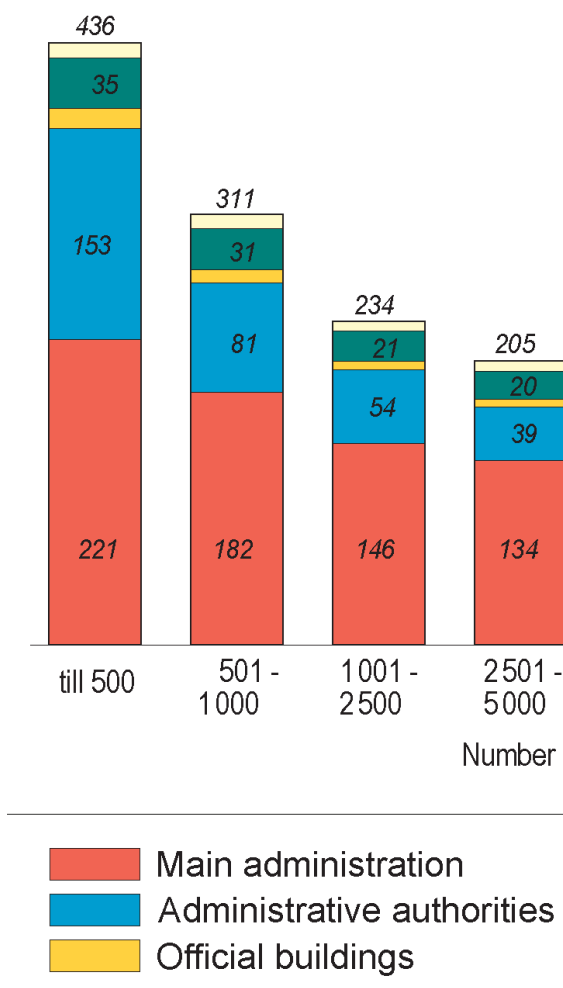

Firefighter and catastrophy services Other expenses

Fig. 2 Administrative expenses of communities per size-class ( $€$ pc) (Kleine Zeitung, Graz, 13.04.2012)

Sl. 2. Administrativni troškovi općina prema veličinskim kategorijama (u Euru po stanoviku) (izvor: Kleine Zeitung, Graz, 13. travnja 2012.)

before (Fig. 2, Kleine Zeitung, Graz, 13.4.2012, 6). According to the Association's calculations, small communes spend almost double as much on administration as the larger ones. The governments of the provinces (Länder) should therefore encourage communes towards fusion, offering financial support or the reduction in duties.

An increasing number of communities sees communal fusion as a historic chance to strengthen their economic and administrative potential, while others find co-operation instead of fusion to be the better solution (Woche, Weiz, 16./18.5.2012, 4f.).

The debate that had arisen on the question between the East Styrian district capital city Weiz and its surrounding communities can be seen as exemplary for the whole country. While the central place pleads for fusion as the best future solution for the whole 
sub-region, guaranteeing economic progress and social stability, the smaller adjacent communes prefer co-operation. They agree that money should not play a dominating role in the discussion since, in the long run, the total budgetary funds for the new extended municipality would not grow significantly - as desired - but only be shifted from the new periphery to the strengthened centre.

As a first step into a new administrative future, 10 communities including the city of Weiz (pop. 2012: 8,928) have founded a regional community association. Its aim is to intensify communal partnership, mutual support, and co-operation in the main fields of spatial planning, zoning, and financing the new partnership region of Weiz (HaberhoferPierzl, Woche Weiz, 9./10.5.2012, 16).

The project of the fusion of 5 communities in the East Styrian sub-region of Birkfeld (Fig. 3, Kleine Zeitung, Graz, 24.7.2012, 14-15) demonstrates that the realizaton of farreaching communal reforms in Austria does not follow a general trend.

Here, the small surrounding communities of the central town of Birkfeld in a marginal mountain region of Styria (pop. 2011: 1.691) are the driving forces for their joining together. They are reckoning on budgetary savings of $€ 400,000.00$ p.a. They project the biggest reduction in communal expenses in the budgetary items for roads and transport ( $€-168,800.00)$, administration ( $€-142,000.00$, services $(€-137,000.00)$, and local authorities (community, councillors, mayors and vice mayors, $€-100,000.00)$. (Pertz, 24.7.2012, 14-15).

\begin{tabular}{|c|c|}
\hline & Savings \\
\hline Administrative authorities & -100000 Euro \\
\hline Management & -142 000 Euro \\
\hline Schools and nurseries & -60000 Euro \\
\hline Roads, traffic & -168800 Euro \\
\hline Economy & -48000 Euro \\
\hline Services & -137000 Euro \\
\hline Finances & -55 000 Euro \\
\hline Total savings & -710800 Euro \\
\hline Initial state & +267 800 Euro \\
\hline Amount & -443 000 Euro \\
\hline
\end{tabular}

Fig. 3 Expected cost-reduction from communal fusion in the Birkfeld region (Styria) (Kleine Zeitung, Graz, 24.07.2012)

Sl. 3. Očekivano smanjenje troškova nakon spajanja općina u regiji Birkfeld (Štajerska) (izvor: Kleine Zeitung, Graz, 24. srpnja 2012.) 
Some experienced communal politicians, however, doubt the soundness of these calculations. Joanneum Research of Graz, a respected research institution, expects savings from fusion of $€ 40 \mathrm{Mn}$. for the whole of Styria, depending on what the communes are going to implement in the end. The saved millions would be put at the communities' disposal for future activities.

\section{CONCLUSIONS}

Communal marginality is not only a phenomenon of remote and/or under-developed regions. It also affects parts of progressive and highly developed states like Austria. The paper addresses in a comprehensive way the various reasons for communal marginality and indicates some possibilities for overcoming the problem. Among them, communal administrative reforms like administrative fusion together with a new "reform-partnership" between the ruling political parties in Styria/Austria are presented as one possible way out of the (present) crisis, especially for the marginalized communes.

The debate on how to overcome the present financial crisis in the European Union has also affected Austrian towns and cities and reaffirmed the necessity for deep-reaching structural reforms within the Austrian administrative structures. After years of quarrelling between the leading political parties, as the first of the federation's nine provinces, the Styrian provincial government decided to start a new era of political co-operation, the so-called "reform partnership". The most significant result of this new policy has been the initiation of communal reform aimed at reducing the number of Styrian communities (2012: 542). Many of them, either for historical reasons or due to remoteness in a mountainous Alpine environment, can hardly survive economically as independent administrative units. Thus, communal fusion seems to open up a chance for overcoming the crisis. However, as a consequence of unreliable information given to the population as well as to communal politicians, deep mistrust and scepticism existed in the beginning. Small communities especially, along with a few economically well-equipped ones, refused fusion and spoke up for co-operation instead, mainly from fear of losing their independence, identity, or their communal infrastructure like kindergartens, primary schools, medicare, shops, etc.

Although these doubts may be justified in some cases, the benefits from well-planned administrative reform prevail. The major communal reform in Styria meanwhile was implemented in 2013. It could be a decisive step towards overcoming communal marginality.

However, there is another aspect that must not be neglected: the fusion of communities usually creates new centres of power and brings about new political players. Since in a democracy the votes after a free election count and decide about the future policy, a change in direction towards strengthening the centres instead of the periphery is likely. 


\section{NOTES}

${ }^{1}$ The term "communal fusion" is a technical one that should not be replaced by other terms.

\section{REFERENCES}

Albertani, C., 2012: Reformieren statt intrigieren. In: Kleine Zeitung, Graz, 4.3.2012, 20-21.

Albertani, C., 2012: Der Mut, das Richtige zu tun, tragt Früchte. In: Kleine Zeitung, Graz, 7.4.2012, 8.

Amt der Steiermärkischen Landesregierung, FA 16, 2012: Gemeindestrukturreform Steiermark - Leitbild. Stärkere Gemeinden - größere Chancen. In: www.gemeindestrukturreform.steiermark.at

Gigler, C. and Kübeck, J., 2011: Liebesheirat als Prinzip ist besiegelt. In: KIeine Zeitung, Graz, 23.11.2011, 16-17.

Hofer, C., 2012: „Nein” zu Fusionierung. In: Woche Graz-Umgebung Südost, Graz, 11.4.2012, 17.

Huberhofer-Pierzl, E., 2012: Liaison aus 10 Gemeinden. In: Woche Weiz, 9./10.5.2012, 16.

Kleine Zeitung, Graz: 7.4.2012, 28.

Kleine Zeitung, Graz: 19.4.2012, 6.

Kübeck, J., 2011: Finanzdruck auf kleine Gemeinden. In: Kleine Zeitung, Graz, 24.11.2011, 20-21.

Patz, U., 2012: 400.000 Euro Mitgift für die Heirat. In: Kleine Zeitung, Graz, 24.7.2012, 14-15.

Pitlink, H., Wirth, K. und Lehner, B., 2010: Gemeindestruktur und Gemeindekooperation. Nov. 2010. http://www.wifo.ac.at/wwa/publd/41359. 35.

Roth, J., 2011: Gemeindestrukturrefom, Bürger, Meister. Leistung. In: Weekend Magazin. Steiermark. Graz, Nr. 23. 10. Dez. 2011, 100.

Rossacher, Th., 2012: In Flussbericht floss viel Kritik, Wasserrahmenrichtline und Asia Spa: Rechnungshofrüge für Steirer. In: Kleine Zeitung, Graz, 8.3.2012, 28.

Schwaiger, G., 2012: So soll die Zusammenlegung von Gemeinden funktionieren. In: Neue Kronenzeitung, Graz, 7.3.3012, 2.

Übelbacher Silberwürfel, 2011: Gebührenvergleich Übelbach, Gemeindezeitung, Nr. 171, 4-5.

Woche Weiz, 2012: Historische Chance oder kooperieren. Weiz, 16./18.5.2012, 4-5. 


\title{
Administrativna reforma kao mjera protiv marginalnosti na lokalnoj razini
}

\author{
Walter Zsilincsar
}

Rad se bavi recentnim administrativnim promjenama u Štajerskoj u Austriji kao načinom rješavanja (većinom fiskalnih) problema, od kojih manje periferne zajednice pate već neko vrijeme. Ti su se problemi povećali s trenutačnom financijskom krizom u većini država članica Europske unije. Metode upotrijebljene u ovom radu uobičajene su u društvenim istraživanjima i demoskopiji i uključuju intervjue s lokalnim političarima i stručnjacima te analizu lokalnih i regionalnih novina i internetskih portala. Autor se u radu poslužio i vlastitom ekspertizom.

Budući da rad nastoji rasvijetliti aktualne procese implementacije administrativnih reformi u austrijskoj pokrajini Štajerskoj te njihovu stvarnu i potencijalnu uspješnost, zaključci o njihovim rezultatima te posljedicama koje će oni izazvati bili bi u ovom trenutku suviše spekulativni. Unatoč tome skreće se pozornost na diskusiju o tome kako primijeniti administrativne ili općinske reforme kao korisno sredstvo u trenutačnoj financijskoj krizi i jesu li njihovi problemi proizašli iz marginalnosti.

U Štajerskoj je monetarna i proračunska kriza uzrkoovala i političke promjene. Dvije najveće političke stranke, Austrijska narodna stranka (konzervativci) i Socijaldemokratska stranka, odlučile su se na pragmatičnu suradnju u rješavanju najhitnijih problema. Konsolidacija lokalnih i regionalnih proračuna tu je dobila prednost.

Prvi odlučni korak u postizanju navedenih cilljeva učinjen je velikim smanjenjem broja općina kako bi se ograničili troškovi birokratskog sustava. Potez se smatrao kontroverznim, a zanimljivo je primijetiti da se ni razlozi „za” ni oni „protiv” nisu mnogo poklapali s programima političkih stranaka, posebice onima koje su dio programa temeljile na pitanjima spajanja općina.

Do 2013. Štajerska se sastojala od 542 općine, od kojih je 76 brojilo manje od petsto stanovnika. Analize iz 2011. pokazale su da 304 štajerske općine očekuje gubitak stanovništva. Mogući rast imigracijom nije se razmatrao. Također 2011. godine devetnaest štajerskih gradova nije uspjelo ostvariti uravnotežen proračun. Neki od razloga jesu visoki troškovi administracije (sl. 2), održavanje komunalne infrastrukture te visoki troškovi obrazovanja i socijalnih davanja. Ono čime se politika nije bavila jest (važna) uloga korupcije i lošeg upravljanja u nizu djelatnosti lokalne i regionalne uprave.

Financijska kriza općina vidljiva je i iz statističkih podataka, iz kojih je moguće razabrati važnost veličine (broja stanovnika) i ekonomske uspješnosti kao presudnih varijabli. Središnje regije i veći gradovi u tom pogledu bolje stoje (sl. 1). Osim mjerljivih indikatora ne smiju se isključiti ni kriteriji lokacije (perifernost ili centralnost). Porezni prihodi potvrđuju tu činjenicu. Daljnja poglavlja fokusiraju se na načine izlaska iz krize, posebice na strukturne administrativne reforme. Najvidljiviji znak tog procesa traženja izlaska iz krize jest novo partnerstvo u regionalnoj vladi. Pragmatična suradnja najvećih stranaka omogućila je pokretanje velikog projekta administrativne reforme koji se temeljio na pitanju kako započeti i implementirati proces spajanja općina. Cilj je tog projekta prepoloviti broj štajerskih općina do 2014. godine.

Na kraju rada predstavljaju se posljedice štajerske reformske politike konsolidacije proračuna, spajanja općina i suradnje, pri čemu se ne zanemaruju kritike, koje su uglavnom išle u smjeru gubitka 
Hrvatski geografski glasnik 76/1 (2014.)

političkog utjecaja na lokalnoj razini. Osim toga jedan od rezultata spajanja općina mogla bi biti i nova funkcionalna podjela novih, većih općina.

Received (Primljeno): 2013 -01-29

Accepted (Prihvaćeno): 2014-03-25

Professor emeritus Walter Zsilincsar University of Graz

Austria

walter.zsilincsar@uni-graz.at 